\title{
Dr. Robert A. LeVine, 2015 Culture, Medicine and Psychiatry Honoree
}

Dr. Robert A. LeVine is honored this year in Culture, Medicine and Psychiatry. Professor LeVine is the Roy Edward Larsen Professor of Education and Human Development, Emeritus, at Graduate School of Education, Harvard University.

As noted in CMP 38(4), Professor LeVine is widely known for his work on the cultural dimensions of childhood and parenting on several continents. More recent work links maternal schooling with child health in Nepal. Dr LeVine is an education and psychological anthropologist and specialist in human development. A full accounting of Dr. LeVine work will be presented in the final number of the year, i.e., volume 39, number 4 , as is the custom now for those honored by CMP.

\section{Previous Honorees}

Margaret Lock (2012)

Renée Fox (2013)

Robert Edgerton (2014) 